\title{
ONTOGENIC DEVELOPMENT OF THE ULTRASTRUCTURE OF BOVINE JOINT CARTILAGE
}

\author{
D. HORKÝ \\ Department of Anatomy, Histology and Embryology, University of Veterinary Science, \\ 61242 Brno
}

Received December 2, 1982

\begin{abstract}
Horký, D.: Ontogenic Development of the Ultrastructure of Bovine foint Cartilage. Acta vet. Brno, 52, 1983: 103-130.

The ultrastructure of chondrocytes and ground substance of the joint cartilage and the surface of this specialized tissue was studied using 4 bovine fetuses aged 246 and 271 days and 3 adults aged 3 to 5 years. Material for the light and electron microscopic study was collected from the carpal and hip joints.

In both fetal and adult cartilage three layers were visible: the superficial, middle and deep layer. In the fetal cartilage, a transitional zone was found between the middle and deep layers. The ultrastructure of chondrocytes and arrangement of the ground substance differed between the layers.

In the superficial layer, single chondrocytes were localized in parallel to the cartilage surface. Zonula nucleum limitans was well developed in cells of the fetal tissue. Among cytoplasmic inclusions, glycogen was found more frequently in the developing cartilage. A characteristic feature of adult cells cytoplasm was the presence of bundles of aperiodic filaments absent from the fetal chondrocytes.

In the middle layer of adult cartilage, the chondrocytes were placed in well developed envelopes of the ground substance. In the fetal cartilage, however, these envelopes were only suggested. In the developing tissue cells glycogen amounts surpassed those found in adult chondrocytes. In fetal cartilage numerous fibrillar structures were found.

In the deep layer of the adult cartilage, $2-3$ chondrocytes were found in one envelope. The numbers and arrangement of organelles did not differ from that of the middle layer. Large amounts of glycogen inclusions were found. In the developing cartilage single cells in one envelope were found. In their cytoplasm granular endoplasmic reticulum was prominent and there were practically no inclusions and fibrillar structures present.

The entire surface of adult joint cartilage was covered with a chondral membrane absent from the developing cartilage except for several small surface areas.
\end{abstract}

Foint cartilage, chondrocytes, ground substance, cartilage surface.

First data on the microscopic structure of human joint cartilage were published more than 100 years ago (Ecker 1843, see Sokoloff 1974), mostly in patho-histological papers in context with description of the so-called "fibrillation" of the cartilage. The chondrocytes were described as clusters of small cells. Later, vast amounts of papers have been published about this specialized structure. In majority of them descriptions have been presented of the histological structure of human joint cartilage in the course of various diseases. Only sporadic data, however, have been published on the microscopic structure of the joint cartilage in other mammalian species. In was not until the technique of tissue culture made it necessary to learn in detail about the joint cartilage structure of experimental mammals and metabolism of its cells (Fischer 1922; Strangeways and Fell 1928, see Sokol off 1974). No major differences have been found in the microscopic structure and tissue cultures in man and experimental animals (for review see Freeman et al. 1973).

Substantial contributions to our knowledge have been achieved by authors studying the submi- 
croscopic structure of both human and animal joint cartilage in great detail such as Barnett et al. (1961), Davies et al. (1962), Palfrey and Davies (1966), Stockwell (1967), Meachim and Stockwell (1973) in the rabbit. These authors presented the classical description of the ultrastructure of chondrocytes and divided the cartilage in 4 layers. They have also studied the appearance and structure of the fibrillar component of the ground substance. A relatively large number of papers deals with the ultrastructure of joint cartilage in mice. Several authors investigated the quantitative relations in the joint cartilage and applied their data to large mammals (Silberger et al. 1961; Fewer et al. 1964; Stockwell 1971ab).

The ultrastructure and surface of the joint cartilage in guinea pig have been studied by Gardner et al. (1981) and Gardner and Woodward (1969).

The joint cartilage of the dog has been investigated with electron microscope using also biochemical methods by Lust et al. (1972) under both physiological conditions and in the course of degenerative processes. The healthy and degenerated joint cartilage of the dog and the horse have been compared by Wiltberger and Lust (1975). A somewhat different approach was that of Lamar et al. (1980) who investigated the ultrastructure of chondrocytes of the joint cartilage in the dog in vivo and in vitro. The cultured chondrocytes retained not only their characteristic shapes but also their submicroscopic structure.

Less attention has been given to the joint cartilage of the pig. The majority of data are collected in the paper of Doige and Horowitz (1975). The joint cartilage of adult individuals has been mostly studied with light microscope. It has also been employed for biochemical studies (An de rs on and Sajdera 1971), and for tissue cultures (Kawiak et al. 1965). Basic data concerning the ultrastructure of the joint cartilage have been presented by S mith et al. (1967), Oryschak et al. (1974), Wolf (1975). The last-mentioned author described the joint cartilage of the horse. As far as the developing joint cartilage of cattle is concerned, the basic data are those by Cameron and Robinson (1958), Brower and Hsu (1969) and Stockwell (1971).

\section{Materials and Methods}

Samples of the joint cartilage were collected from 3 adult cattle aged 3 to 5 years, and from 4 bovine fetuses aged 246 to 271 days. The samples were collected from the convex aspects of the joint heads from the carpal and hip joints for both light and electron microscopy. Tissue stripes $1 \times 1 \times 3.5 \mathrm{~mm}$ were cut out and divided in blocks $1 \times 1 \times 1-2 \mathrm{~mm}$.

The samples were immediately fixed in $4 \%$ glutaraldehyde in $0.1 \mathrm{M}$ phosphate buffer, $\mathrm{pH} 7.4$ in two rinses (60 and 180 minutes). All specimens were then decalcified in $0.1 \mathrm{M}$ EDTA solution in $4 \%$ glutaraldehyde, $\mathrm{pH} 7.4$ in two rinses (60 minutes each), and left in the decalcifying fluid overnight. The last rinse was prolonged to 75 minutes. The specimens were then washed in 3 changes of $0.1 \mathrm{M}$ phosphate buffer, $\mathrm{pH} 7.4$ and fixed with $1 \% \mathrm{OsO}_{4}$ in phosphate buffer, $\mathrm{pH} 7.4$ for 15 and 45 minutes. They were dehydrated with graded acetone series ( $25 \%$ anhydrous acetone); in $90 \%$ and anhydrous acetone the dehydration was finished with two 30-minute rinses. The infiltration was carried out in a standard way and the samples were embedded in Durcupan ACM and polymerized at $60^{\circ} \mathrm{C}$ in a thermostat for 3 days.

Ultrathin sections were cut on an Ultracut Reichert microtome and stained with lead citrate according to Reynolds or with $1 \%$ uranyl acetate followed by lead citrate. The sections were viewed and photographed with a Tesla BS 613 and Tesla BS 500 electron microscopes. From the embedded material also semithin sections for light microscopy were cut and stained with $1 \%$ methylene blue and $1 \%$ Azur II. Another portion of the collected material was embedded in paraffin and employed for morphometric studies.

\section{Results}

\section{Ultrastructure of the joint cartilage in adult cattle}

Both light and electron microscopic studies have revealed that the chondrocytes in the joint cartilage of man and animals are arranged in three layers: the superficial, middle and deep layer (Palfrey and Davies 1966; Meachim 1969; Vignon et al. 1976 and others). We shall hold to this division although another group of writers found four chondrocyte layers: the superficial layer, the superficial zone of the middle layer, the deep zone of the middle layer, and the deep 
layer (Davies et al. 1962; Barnett et al. 1963). However, more recent data and our own results suggest that the division of the cartilage in three layers corresponds well with the ultrastructural characteristics of this specialized tissue.

\section{Superficial layer of the cartilage}

Chondrocytes of the superficial layer were spindle-shaped, elongated cells $5 \times$ $\times 10-13 \mu \mathrm{m}$ in size. Their long axes were parallel to the cartilage surface (Fig. 1). Sectioned cells were mostly ellipsoid in shape and they were placed in lacunae in the ground substance usually single, exceptionally in pairs.

\section{The nucleus}

Chondrocytes of the superficial layer from adult joint cartilage contained one ovoid or slightly lobulated nucleus separated from the adjacent cytoplasm only by a nuclear envelope with shallow invaginations.

The nuclear envelope had the usual appearance. Few ribosomes were attached to its outer membrane which passed into membranes of the granular endoplasmic reticulum.

The nuclear chromatin was mostly arranged in karyosomes situated near the nuclear membrane and in several smaller clusters outside the nuclear envelope. There was no zonula nucleum limitans developed.

The nucleolus was not regularly present in chondrocytes of the superficial layer. When present it was rather large and reticular in type.

\section{The cytoplasm}

A characteristic feature of chondrocytes in the superficial layer of the joint cartilage was a relatively large number of cell organelles (Fig. 2) and cytoplasmic fibrillar structures (Fig. 1) whereas cytoplasmic inclusions (lipid droplets and glycogen) were rather scarce.

Granular endoplasmic reticulum was arranged in short cisterns and vesicles (Fig. 1 and 2). The cisterns were scattered irregularly throughout the cytoplasm among other organelles. Few of them were connected with the outer membrane of the nuclear envelope. The vesicles of the granular endoplasmic reticulum did not exceed $0.3 \mu \mathrm{m}$ in diameter. Numerous ribosomes were attached to both vesicles and cisterns. The inner spaces of both forms of the granular endoplasmic reticulum were almost invariably filled with homogenous material of medium electron density.

Agranular endoplasmic reticulum was only rarely seen in the cytoplasm of chondrocytes of the superficial layer. When present it formed small smooth vesicles, possibly originating from the Golgi complex.

The Golgi complex was composed as in other cell types of a system of flattened cisterns, small and larger vesicles (Fig. 1 and 2). In sectioned cells, the Golgi complex was arranged in several Golgi fields. Both cisterns and vesicles usually contained material of medium electron density.

Mitochondria did not differ from those of other somatic cells (Fig. 1). In sections they appeared oval to round with few cristae. Rarely the mitochondrial bodies were found. They were situated irregularly and there was no topographic relationship to cellular inclusions, e. g. lipid droplets. 


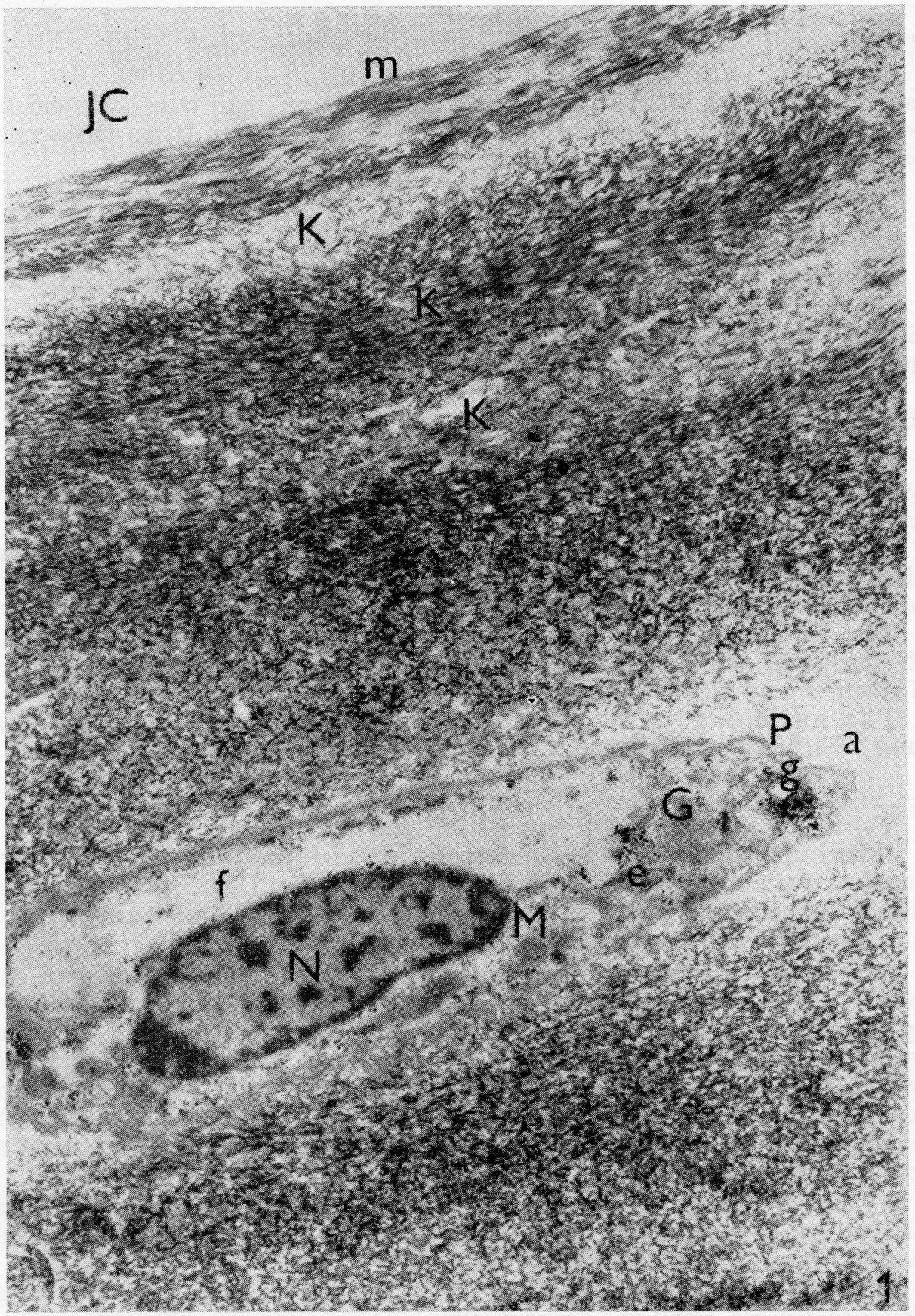

Fig. 1

A portion of the superficial layer of the adult bovine cartilage. Adjacent to the joint cavity (JC) is the chondrosynovial membrane $(\mathrm{m})$. Towards the inner layers of the cartilage, layers of collagenous fibres $(\mathrm{K})$ course almost perpendicular to each other. The nucleus $(\mathrm{N})$ of a chondrocyte, granular endoplasmic reticulum (e), mitochondria (M), Golgi complex $(\mathrm{G})$ are distributed in several areas, glycogen (g), a large bundle of filaments (f) is placed above the nucleus and partly surround it. The projections of the cell membrane $(P)$ reach to the pericellular zone (a). $\times 9800$. 


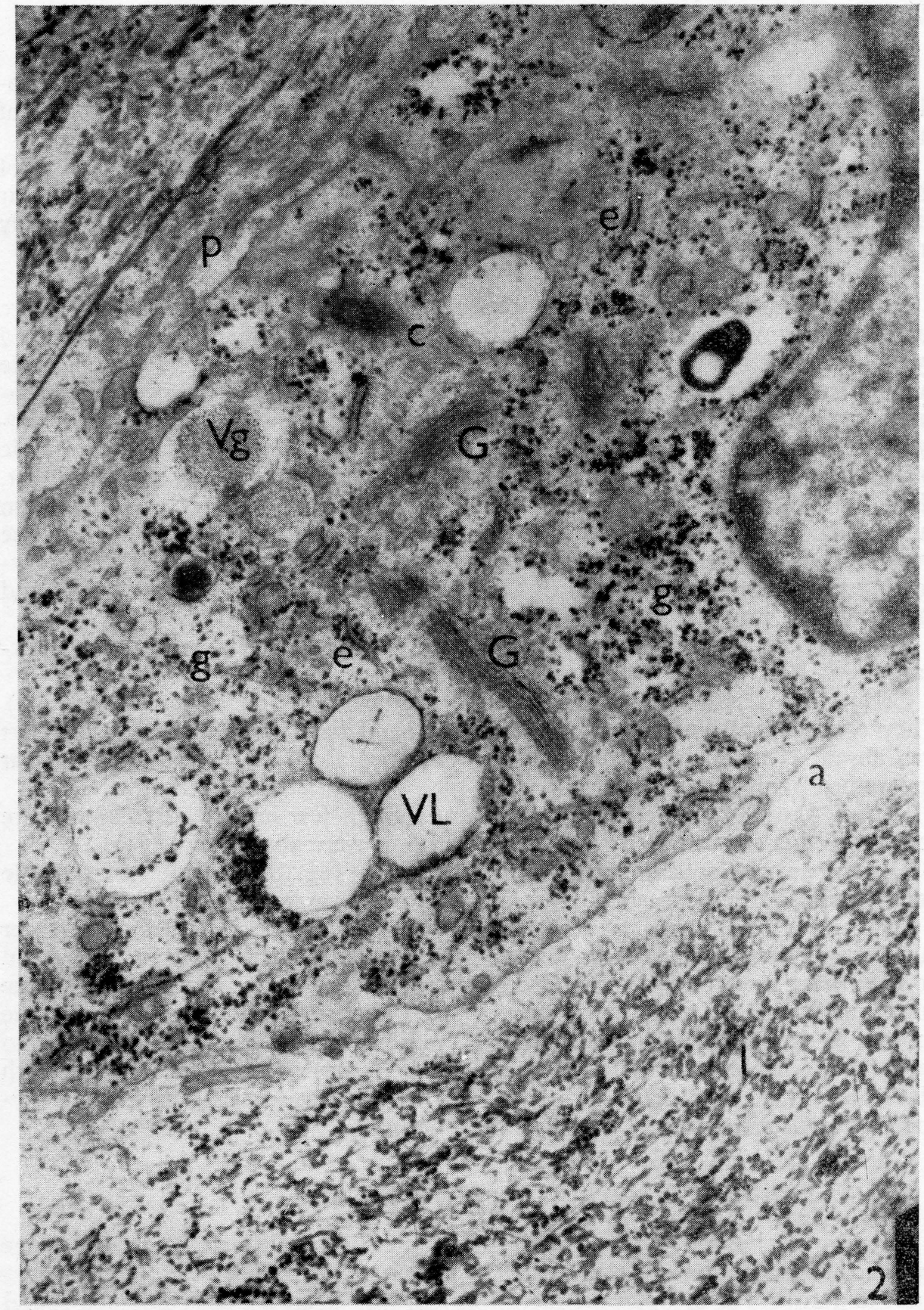

Fig. 2

A portion of the cytoplasm of a chondrocyte in the superficial layer of the adult bovine joint cartilage. The Golgi complex (G) is in several fields, short cisterns of the granular endoplasmic reticulum (e), sectioned atypical cilia (c), vacuoles containing light, mesh-like material (VL), or granular material (Vg.) Glycogen grains (g) are disseminated throughout the cytoplasm. Short projections of the cell membrane (p) reach only the pericellular zone (a). Beyond this zone, intercellular matrix (I) is present. $\times 21400$. 
Ribosomes were mostly attached to the membranes of the granular endoplasmic reticulum. Only few of them were present in the cytoplasm in form of monosomes; polysomes were found only exceptionally.

Lysosomes though few in number were found regularly in the cytoplasm of chondrocytes (Fig. 2). They were covered with a simple membrane and their size reached $0.5 \mu \mathrm{m}$. They contained electron dense, homogenous or coarsely granular material.

Microtubules and centrioles were not found in our material.

The cell membrane. The cytoplasm formed short prominences on its entire surface. They occurred at various distances from one another and were covered by the cell membrane. They were up to $1 \mu \mathrm{g}$ long and $0.5 \mu \mathrm{m}$ wide, and simple in most cases (Fig. 1,2). They reached only to the pericellular matrix; exceptionally they penetrated into the intercellular substance. The surface of some chondrocytes or portions of the surface were rather smooth. Between the cytoplasmic projections and on the smooth cell surfaces pinocytotic vesicles were present. Near the cell membrane of some chondrocytes smooth vesicles reaching $2 \mu \mathrm{m}$ in size, filled with medium osmiophilic, finely granular material were found. These were presumably the so-called "transport vesicles" or "secretory vacuoles" transporting the material synthesized in the Golgi complex to the cell membrane and then excreted into the extracellular space.

Supporting structures of desmosome type were not found in our material.

Cilia were occasionally found in chondrocytes of the superficial layer (Fig. 2). They consisted of kinetosome and the peripheral part proper; the striated part was absent. Our material provided no evidence for an atypical microtubular apparatus.

Lipid droplets were regularly present though few in numbers. They were covered with a smooth membrane and their sizes were about $1 \mu \mathrm{m}$ (Fig. 2).

Glycogen was present in small amounts only (Fig. 1 and 2), forming single beta granules grouped in small areas or scattered throughout the cytoplasm.

Cytoplasmic fibrillar structures were as smaller or occasionally larger bundles of fine filaments (Fig. 1) localized in the ground cytoplasm. They had no membrane and were usually situated perinuclearly. They were attached to the outer membrane of the nuclear envelope. They were closely attached to one another in the bundles and were arranged more or less in parallel. There was no periodicity visible in longitudinal sections. The cytoplasmic areas filled with filaments did not contain any further structures or organelles. Only rarely glycogen granules were found between the bundles.

\section{Middle layer of the cartilage}

Chondrocytes of the middle layer of the joint cartilage differed from those of the superficial layer not only in shape but also in arrangement of several cell organelles and the numbers of cytoplasmic inclusions. In this layer, the cells assumed round or ellipsoid shape and their sizes were not different from those found in the superficial layer. The cells were arranged in their envelopes single or mostly in pairs (Fig. 3 and 4 ).

The nucleus was irregularly oval or triangular, occasionally irregular in shape. The shape of the nucleus assumed almost exactly the shape of the cell. 


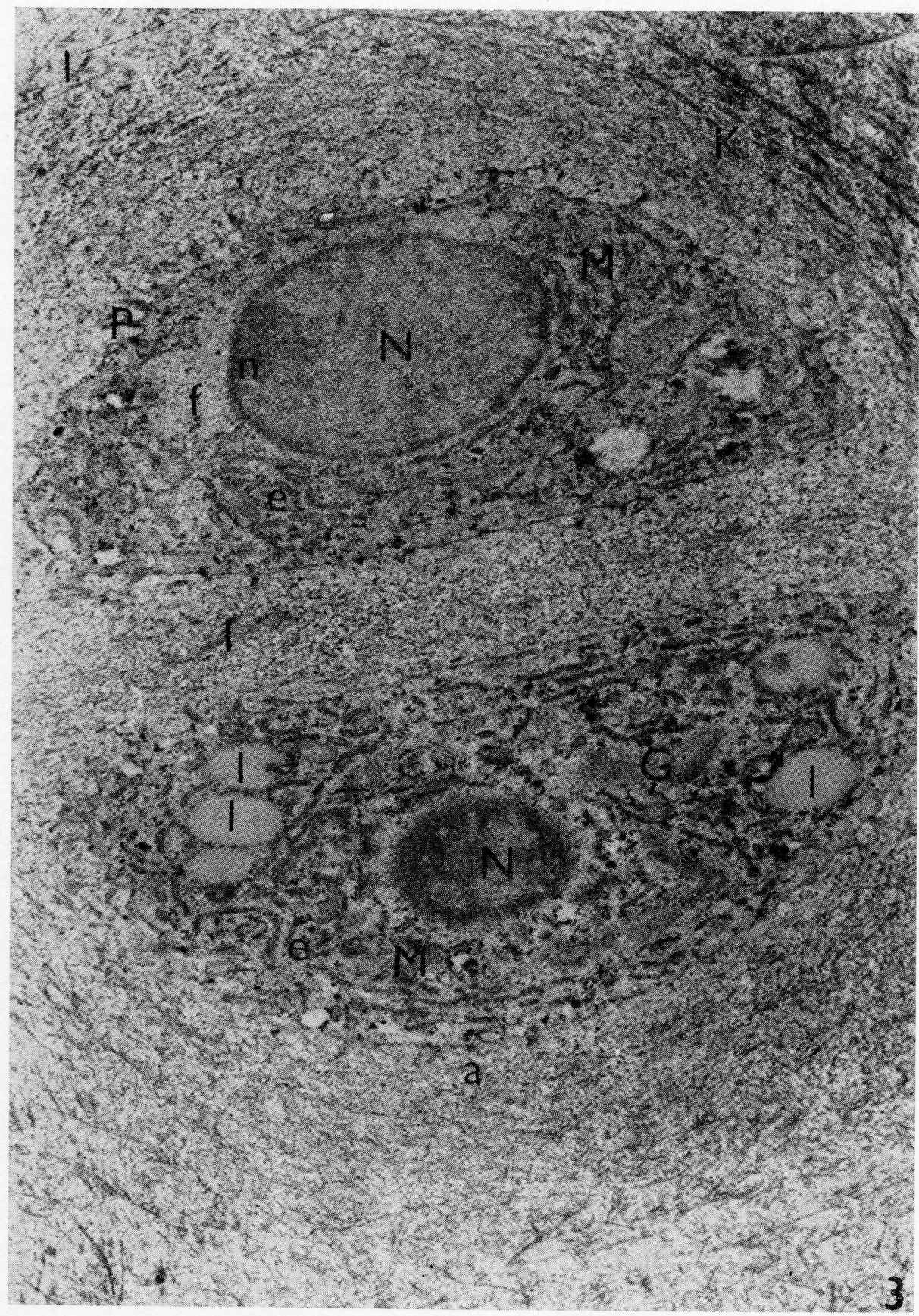

Fig. 3

A pair of chondrocytes in the middle layer of the joint cartilage of an adult bovine, located in one envelope of pericellular matrix (a), surrounded by collagenous fibres $(\mathrm{K})$ forming the intracellular matrix (I). The nucleus (N) and nucleolus (n), cisterns of the granular endoplasmic reticulum (e), Golgi complex (G) are well developed; minute mitochondria $(\mathrm{M})$ are disseminated irregularly among the lipid droplets (l) and bundles of filaments (f). Short projections of the cell membrane (P) do not reach the pericellular substance. $\times 9800$. 


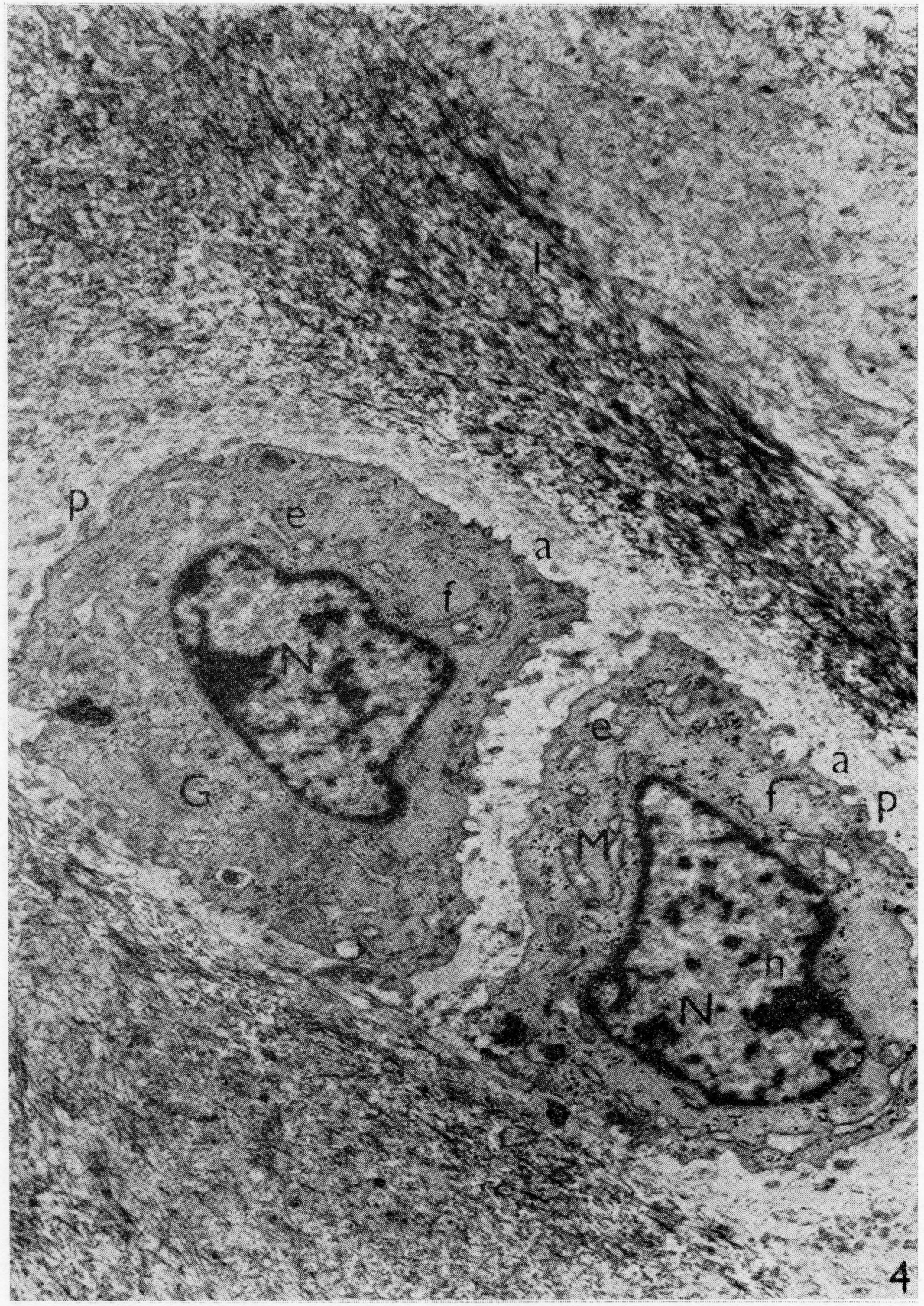

Fig. 4

A pair of chondrocytes from the deep portion of the same layer as in Fig. 3. The pericellular zone (a) is well developed. Short projections of the cell membrane (p) reach (a). Beyond this zone filled with aperiodic fibrils, concentrically arranged collagenous fibrils forming the intracellular substance (I) are visible. Cisterns of the granular endoplasmic reticulum (e) are dilated, the Golgi complex (G) is arranged in the same way as that shown in Fig. 3, in the cytoplasm numerous bundles of filaments $(\mathrm{f}) . \times 9800$. Mitochondria $(\mathrm{M})$, nucleus $(\mathrm{N})$, nucleolus $(\mathrm{n})$. 
Nuclear envelope had the usual structure. It sometimes formed shallow invaginations. To its outer membrane ribosomes were attached, in some areas more densely but, in general, they were rather scarce. The perinuclear space was narrow, only exceptionally wider and in some cases a connection with the cisterns of the granular endoplasmic reticulum was suggested. There was no zonula nucleum limitans developed.

Chromatin was organized in a similar way as in chondrocytes ot the superficial layer or the karyosomes were but small and formed a more or less continuous lining attached to the inner membrane of the nuclear envelope. The rest of the nuclear surface area was light in sections (Fig. 3 and 4).

The nucleolus was found more frequently in sectioned nuclei of chondrocytes of the middle layer than in those of the superficial layer (Fig. 3 and 4). We invariably found the reticular type of nucleolus.

The cytoplasm assumed larger areas of the sectioned cells (with semiquantitative evaluation) and contained a larger number of organelles than that of the cells in the superficial layer of the cartilage.

Granular endoplasmic reticulum (Fig. 3 and 4) was arranged in two ways in the cytoplasm of chondrocytes of the middle layer. It was arranged either in rather short, numerous flattened cisterns (Fig. 3) some of which were wider at the ends. Their course was irregular among the other organelles. In majority of cases, there were simple cisterns, only occasionally they branched or were interconnected with the adjacent ones. The granular endoplasmic reticulum was densely packed with ribosomes in contrast to that of chondrocytes in the superficial layer.

The second type of cisterns was a dilated one (Fig. 4), filled with medium osmiophilic, finely granular material.

Agranular endoplasmic reticulum occurred only occasionally in the chondrocyte cytoplasm of the middle layer of the joint cartilage, similar to findings in the superficial layer.

The Golgi complex was regularly found and it was arranged in several Golgi fields. From its widening cisterns small and larger vacuoles separated. These were filled with material of moderate electron density. Structures of the Golgi complex were mainly localized in perinuclear areas.

The numbers of mitoch ondria differed from findings in the superficial layer. Their shapes, however, were often almost rod-like, especially in cells of the transition area between the middle and deep layers.

Ribosomes were mostly bound to the membranes of the granular endoplasmic reticulum.

Lys osomes were rare in the cytoplasm of middle layer chondrocytes (Fig. 4). When found, they appeared as electron dense bodies up to $0.8 \mu \mathrm{m}$ in size, covered with a smooth membrane which was hard to demonstrate.

Microtubules and centrioles were not found in the cytoplasm of chondrocytes of this layer.

Cell membrane. Various numbers of projections were coated by the cell membrane. They were less numerous on cell surface facing each other, their length was $0.5 \mu \mathrm{m}$ to $0.8 \mu \mathrm{m}$. They were mostly simple and some of them crossed the lacuna and reached the intercellular ground substance. The cell membrane formed few pinocytotic vesicles.

Desmosomes and cilia were not found in this cartilage layer. 
Lipid droplets were present in various numbers. Their size was up to $2 \mu \mathrm{m}$, and they were enclosed by smooth membranes and contained homogenous, light material.

Glycogen was found only in small amounts and in the form of small granules disseminated in the cytoplasm.

Cytoplasmic fibrillar structures were similar to those found in chondrocytes of the superficial layer (Fig. 4), the only difference being smaller sizes of the bundles. The "secretory transport" vacuoles were found rarely.

\section{Deep layer of the cartilage}

Chondrocytes of this layer were somewhat smaller as compared to those of the above-mentioned layers; their sizes were about $8 \times 10 \mu \mathrm{m}$ and their shapes were more variable, e. g. irregularly prismatic, arranged in columns perpendicular to the surface of the cartilage. The cells were in groups of 2 or 3 in one envelope (Fig. 5). The lacunae were separated by a layer of interfibrillar substance but the chondrocytes within one lacuna were closely attached to each other with no septa or pericellular matrix. Often degenerating chondrocytes were found (Fig. 6).

\section{The nucleus}

was mostly round (Fig. 5) with shallow invaginations of the nuclear envelope to which few ribosomes were attached. The perinuclear space was narrow, there was no zonula nucleum limitans.

Nuclear chromatin was arranged in a way similar to that in cells of the superficial and middle layers.

The nucleolus was rarely found; it was usually one of reticular type.

\section{The cytoplasm}

was less voluminous than in cells of the middle layer and the nucleous: cytoplasm ratio was shifted in favour of the nucleus.

Granular endoplasmic reticulum did not differ in size and arrangement from that in the middle layer. However, more frequently areas of granular endoplasmic reticulum without attached ribosomes were seen.

Agranular endoplasmic reticulum was very rare and it was usually near the cell membrane. It was hard to distinguish from pinocytotic vesicles or Golgi complex vesicles as these contained material of the same electron appearance as was found in pericellular spaces.

The Golgi complex was very small and not visible in all sections.

Mitochondria did not differ from those found in the above-mentioned layers' chondrocytes except for the rather high density of their matrix.

Ly s os omes were regularly found (Fig. 5) and also in chondrocytes of the deep layer they formed dark bodies about $0.2-0.5 \mu \mathrm{m}$ in size.

Cell membrane. The cytoplasm of chondrocytes in the deep layer formed fewer projections than that in the middle layer. The projections were branched and they occasionally reached the intercellular substance. There were few pinocytotic vesicles. At the periphery of some chondrocytes under the cell membrane large vacuoles containing dense, coarsely granular material were found.

Lipid droplets were not observed in chondrocytes of the deep layer.

Glycogen was regularly found in chondrocytes of this layer. It was located 


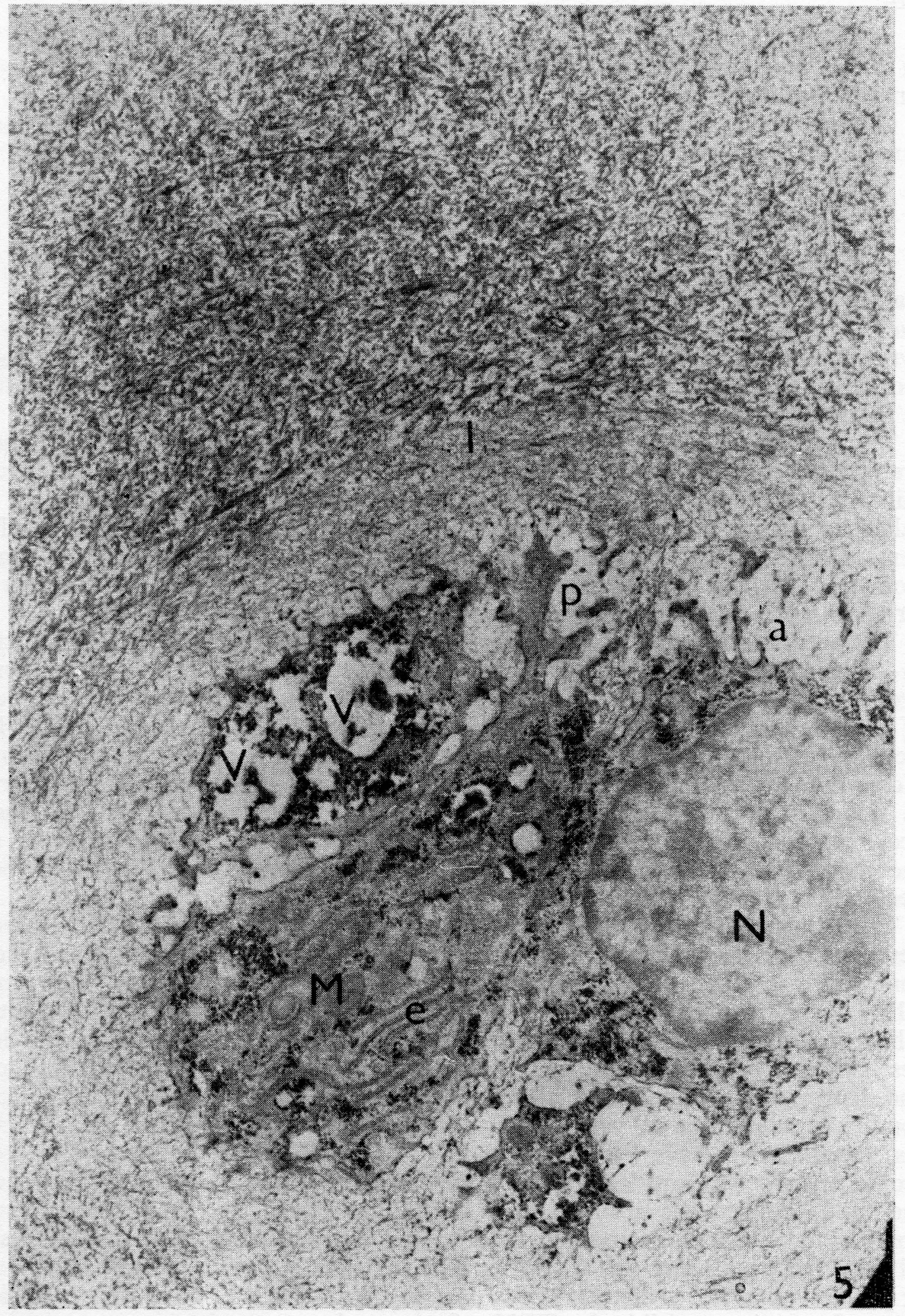

Fig. 5

A sectioned lacuna with chondrocytes of the deep layer of the joint cartilage in an adult bovine. Nucleus $(N)$ is round, cisterns of the granular endoplasmic reticulum (e) are only narrow. Among them, mitochondria $(\mathrm{M})$, glycogen fields (g) in some cases with vacuoles (V), are placed. The cell membrane projections (f) do not reach beyond the pericellular zone (a) in the intercellular substance $(\mathrm{I}) . \times 9800$. 
in several small areas in peripheral cytoplasm between cell organelles, and also in smaller vacuoles.

Gytoplasmic fibrillar structures were rarely found; they formed small bundles of aperiodic filaments disseminated in the cytoplasm.

\section{Submicroscopic structure of the ground substance of cartilage}

The ground substance of the cartilage is composed of the fibrillar ground substance and amorphous ground substance. These components are arranged in such a way that 1) specialized area located in the immediate vicinity of chondrocytes designated as pericellular matrix, and 2) the remaining ground substance located outside this area among chondrocytes of groups of chondrocytes designated as intercellular matrix, can be distinguished.

The ground fibrillar matrix is mostly formed by typical collagen fibrils. They are striated in such a way that lighter and darker segments, visible in electron microscope, interchange regularly at a distance of $64 \mathrm{~nm}$. This phenomenon is called periodicity (Boni and Monteleone 1957). In the joint cartilage, the collagenous fibrils $30-80 \mathrm{~nm}$ wide were the most frequently occurring ones. Apart from these typical fibrils single, much wider fibrils with conspicuous transverse striation (more that $150 \mathrm{~nm}$ wide) were detected.

The second component of the ground fibrillar substance were the fine fibrils (4-10 nm wide) of various lengths present in largest amounts in the area of chondrocyte envelope (pericellular matrix) where they formed a substantial portion of the intercellular substance. These fine filaments showed no periodicity. The electron-microscopic study alone does not clearly show their collagenous nature. However, they would be the only fibrillar component of the pericellular matrix as this area is lacking other collagenous fibrils. Filaments $4-10 \mathrm{~nm}$ wide may occur in small numbers between the collagenous fibrils in the superficial zone of the intercellular substance of the cartilage. They are the exclusive fibrillar component of the so-called lamina splendens.

The amorphous ground substance filled the spaces between the fibrillar components and connected the individual fibrils. It was composed of protein polysaccharide complexes, so-called mucopolysaccharides or, more exactly, glycosaminoglycans. Their typical representatives are e. g. chondroitin sulphate and keratin sulphate. Their molecular weight is about $4 \times 10^{6}$ and they aggregate to form large complexes. Detailed biochemical and histochemical studies have revealed the composition and distribution of the individual components of the cartilage under physiological conditions as well as in various disturbances of metabolism of the chondrocytes. Detailed data have been presented by Muir (1973). In the electron-microscopic field fine meshwork is visible in the area of pericellular matrix and between the typical collagenous fibrils in the intercellular matrix. The meshwork is composed of fine filaments interconnected at acute angles. Some filaments had suggested periodicity but there was no evidence as to their nature (collagenous filaments or protein- polysaccharide complexes or aggregates of both). They were reminiscent of structures visible in TEM after protein-polysaccharide precipitation (Rosenberg et al. 1970). 
Arrangement of the ground fibrillar substance in the intercellular matrix of the cartilage

The superficial layer of the adult cartilage in the bovine is covered by a 0.5 to $1 \mu \mathrm{m}$ thick layer composed of two basic components. One of the components is formed by fine fibrils $4-10 \mu \mathrm{m}$ wide and inserted in the amorphous ground substance (Fig. 1). The reticular composition is visible at great magnification, and its irregular arrangement may be seen especially in areas where the amorphous substance had been removed. The superficial layer has been described in light microscopic field and named lamina splendens. Wolf (1975) used the designation chondral membrane. Later TEM studies have revealed its composition of fine fibrils and ground amorphous substance. Its thickness is $0.5-1 \mu \mathrm{m}$ in adult intact cartilage. In our specimens it was $0.5-1.0 \mu \mathrm{m}$ thick. The differences in thickness may be attributable to the site of collection, age of the animal and joint type. However, the most important is the effect of age. Thus in newborns, thickness of $12 \mu \mathrm{m}$ has been given by Cameron and Robinson (1958) who found it to decrease with advancing age. The surface of the joint cartilage is not entirely smooth. Various prominences may be seen with underlying collagen fibrils reaching from deeper layers. In healthy cartilage they are covered with a confluent surface layer (Bozděch et al. 1974).

Beneath the chondral membrane, in the superficial layer of the cartilage, collagen fibres $30-80 \mu \mathrm{m}$ thick and several $\mu \mathrm{m}$ long were seen. They were closely attached to one another, sometimes forming fascicles oriented in parallel with the cartilage surface. Exceptionally bundles of collagen fibres perpendicular to the cartilage surface were found. They were connected by small amounts of the amorphous ground substance.

Collagen fibres on the surface of the joint cartilage were arranged in layers differing by amounts of the amorphous ground substance and course of the fibrils. In sections perpendicular to the cartilage surface, interchange of lighter and darker layers was seen (Fig. 1). Density of these layers was dependent upon the amount of the amorphous ground substance and density of the fibres. Further, regularly interchanging layers of longitudinally and transversely passing collagen fibrils were found. Near the cartilage surface, these layers were well visible but near the middle layer they were confluent. Among the collagen fibres of the superficial layer the chondrocytes were located, whereas in the chondral membrane no cells were detected.

In the middle layer of the cartilage changes occurred in the arrangement of the fibrillar ground substance and in the ratio of the fibrillar and amorphous ground substance. Collagen fibres similar to those of the superficial layer formed two kinds of bundles: at sites where they were attached to the pericellular matrix they run in parallel with the surface of chondrocytes and they formed a web around the whole area (Fig. 3 and 4). Outside these areas the bundles are arranged in an irregular pattern (McCall 1969) as long as they are not subject to pressures. In response to external pressure load, the fibres and bundles have been found to assume the position perpendicular to the effect of load.

The ground substance of the deep layer of the joint cartilage is characterized by irregular arrangement of the collagenous fibrils forming less bundles than in the middle layer (Fig. 5 and 6). Some of the bundles were oriented perpendicular to the cartilage surface and were placed among chondrocytes arranged 


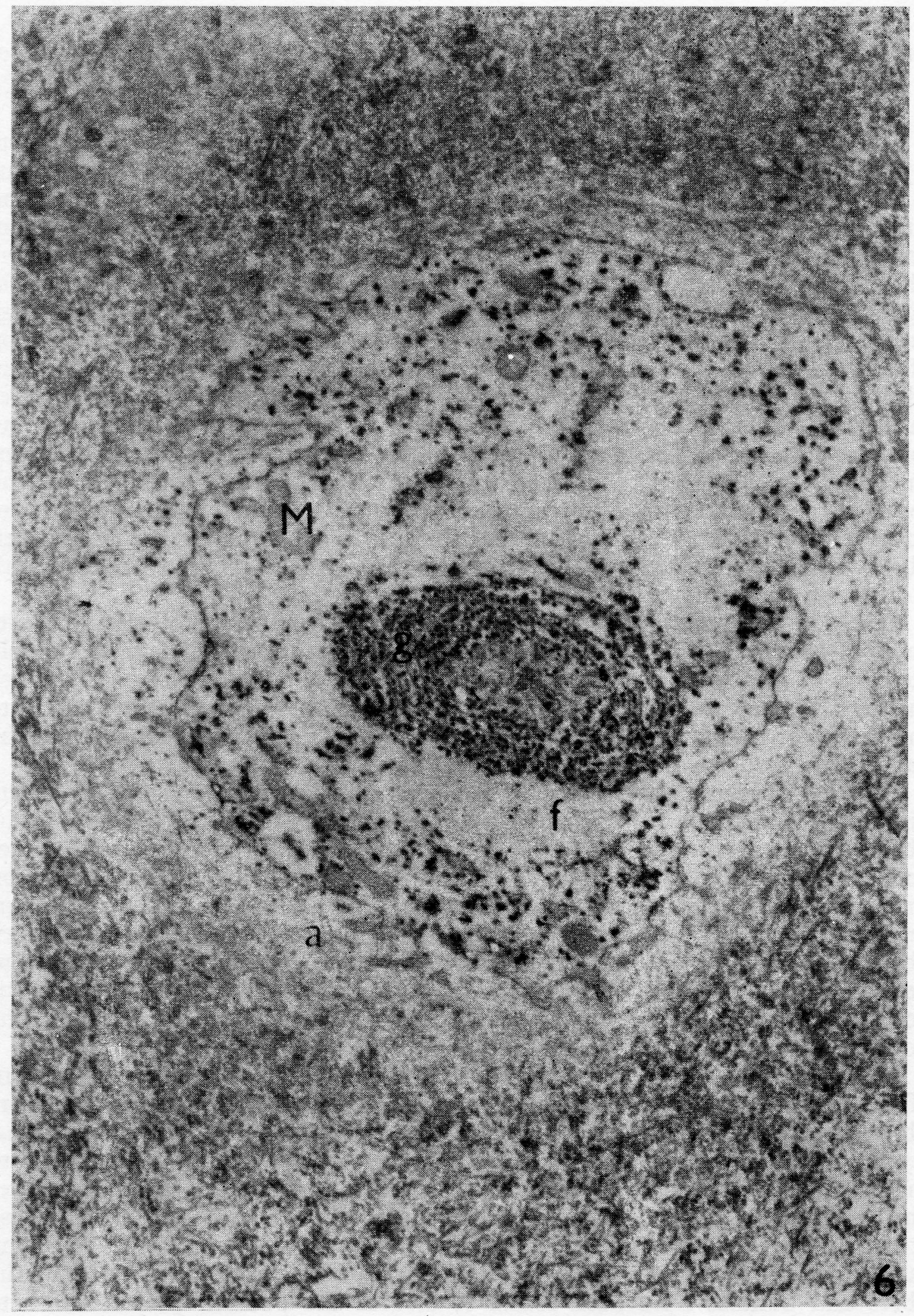

Fig. 6

A degenerating chondrocyte from the deep layer of the joint cartilage of an adult bovine. In the cytoplasm concentrically arranged lamelles with glycogen granules (g), mitochondria (M) and filaments (f) are visible. The pericellular matrix is preserved (a). $\times 11800$. 
in columns. The amount of the amorphous ground substance did not differ from that found in the middle layer so that its appearance was mesh-like in this layer, too. The pericellular matrix formed a thin area close to the cell membrane of the chondrocyte. This area often disappeared at one side and the collagen fibres from the adjacent ground matrix reached the cell membrane. $\mathrm{McCa}$ Cll's (1969) electron-microscopic studies have revealed that with experimental application of pressure changing the spatial arrangement of collagen fibrils in the middle layer, those present in the deep layer remain unaffected.

\section{Submicroscopic structure of the joint cartilage in the fetal period}

Our light and TEM studies revealed the above-mentioned cartilage layers in bovine fetuses, too. However, they were not separated as clearly as in adults. This finding supports the data of Cameron and Robinson (1958), Brower and Hsu (1969) and Stockwell (1971).

\section{Superficial layer of the cartilage}

Chondrocytes of this layer did not differ from cells of the adult animals. They were spindle-shaped, $3-5 \times 10-12 \mu \mathrm{m}$ in size and their longitudinal axes were parallel with the surface of the cartilage (Fig. 7). They were mostly single, only exceptionally cells placed beneath one another were found (Fig. 8).

\section{The nucleus}

Chondrocytes of the superficial layer had one rather large nucleus. Their envelope showed no larger irregularities. Few ribosomes were attached to the outer membrane which often passed to structures of the granular endoplasmic reticulum.

Nuclear chromatin was arranged in karyosomes near the nuclear envelope. The rest of the nucleus was transparent to the electron beam. There was a zonula nucleum limitans in the form of a thin ring attached to the internal of the nucleus (Fig. 7).

The nucleolus was frequently found. Its appearance was reticular.

\section{The cytoplasm}

The submicroscopic appearance of cytoplasm of the chondrocytes in the superficial layer was different in cells located beneath the cartilage surface (Fig. 7) as compared to cells located deeper in this layer (Fig. 8), especially in the amount of cytoplasmic inclusions.

Granular endoplasmic reticulum was arranged in short cisterns and vesicles (Fig. 8) as in adult cartilage without regular pattern; they were located in the ground cytoplasm among other organelles. Their inner spaces were filled with homogenous material of moderate electron density.

Agranular endoplasmic reticulum formed single smooth vesicles near the cell surface (Fig. 7). In some cases it was difficult to distinguish it from folds of the cell membrane.

The Golgi complex had the usual structure. In chondrocytes of the superficial layer it was arranged in several Golgi fields (Fig. 8), located mostly in perinuclear area. From its flattened cisterns a number of small vesicles separated 


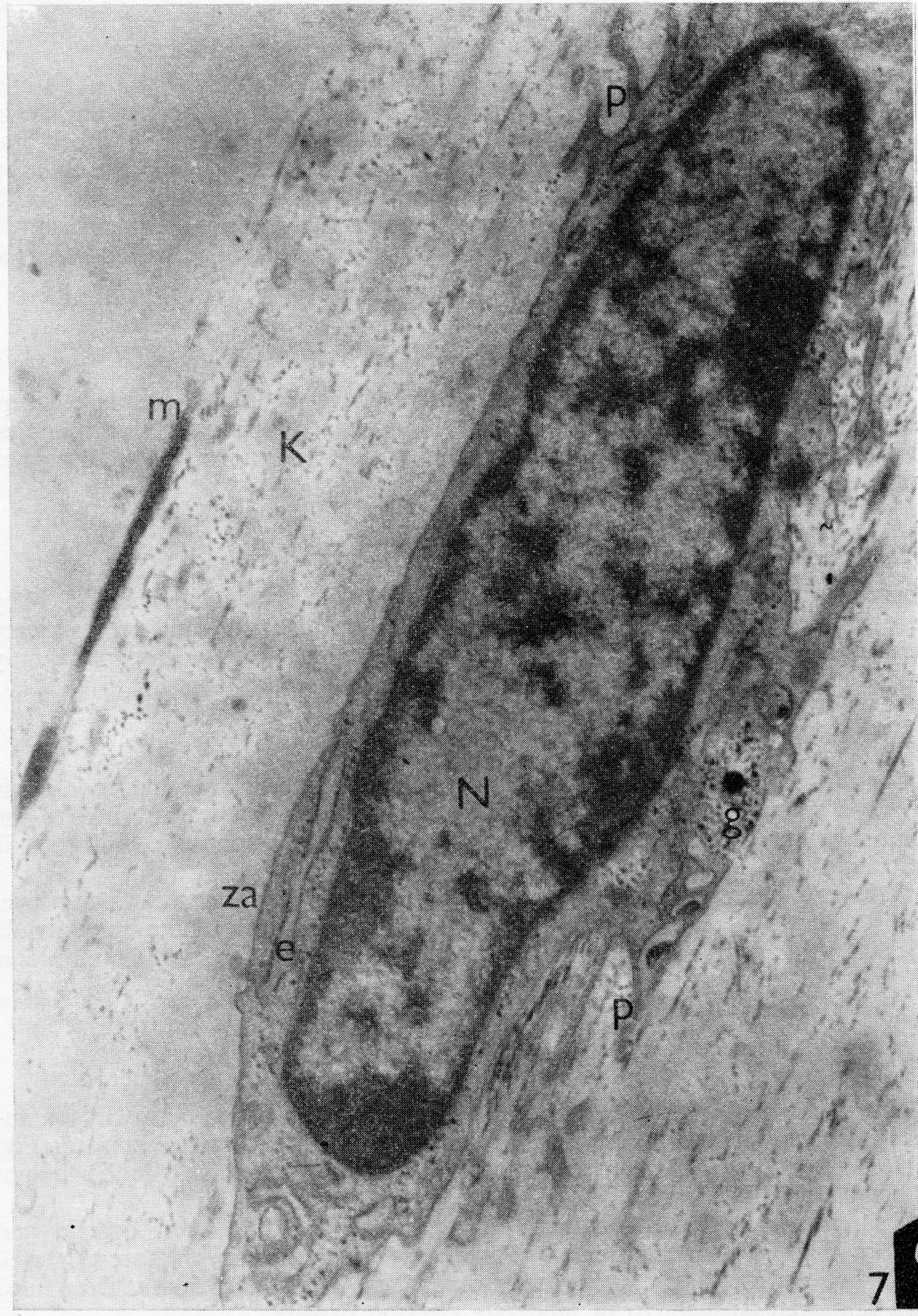

Fig. 7

A chondrocyte from the superficial layer of the joint cartilage of a bovine fetus. The nucleus (N), zonula nucleum limitans (z). In the cytoplasm cisterns of the granular endoplasmic reticulum (e), glycogen granules $(\mathrm{g})$ are visible. No pericellular zone is formed, the cytoplasmic projections (p) reach the intercellular substance, where the amorphous ground substance (za) predominates over few collagenous fibres $(k)$. On the cartilage surface a portion with forming chondral membrane is present $(\mathrm{m}) . \times 21400$. 


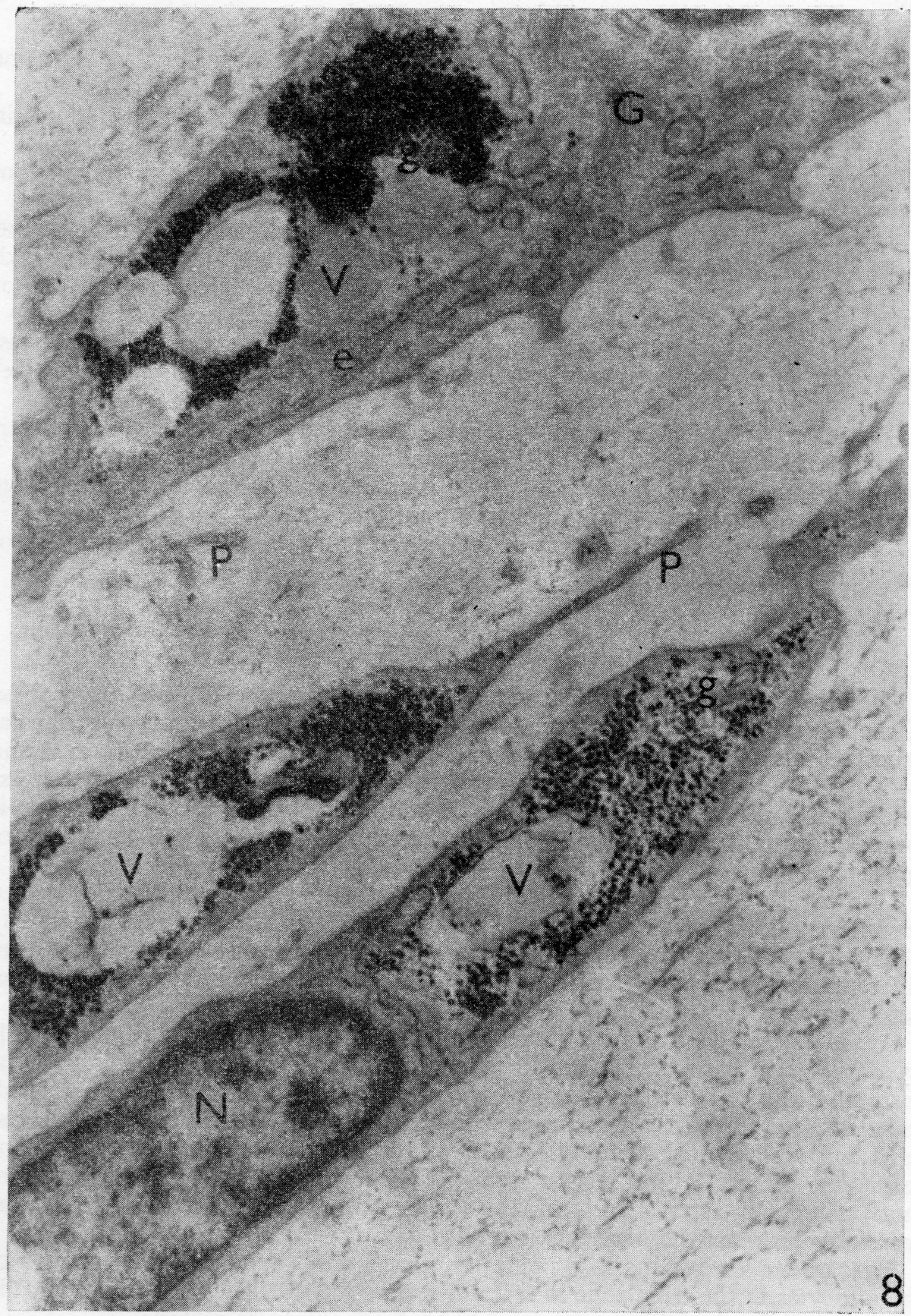

Fig. 8

A portion of a group of chondrocytes in the superficial layer of the fetal joint cartilage. The nucleus $(\mathrm{N})$, cisterns of the granular endoplasmic reticulum (e), the Golgi complex $(\mathrm{G})$, with small and larger vesicles (V). Glycogen ( $\mathrm{g}$ ) is located in large along with large vacuoles (V) containing different material. The short projections of the cell membrane $(p)$ reach the intercellular substance of the same appearance as in Fig. $7 . \times 21400$. 
and remained in close vicinity, and large vesicles containing material of the same appearance as that in cisterns of the granular endoplasmic reticulum.

Mitochondria were few in number and did not differ from those found in chondrocytes of the adult cartilage.

Lysosomes were seen only rarely in fetal cartilage, and their size did not exceed $0.3 \mu \mathrm{m}$.

Cell membrane. The cytoplasm of chondrocytes formed a few short and rather thick projections maximum $1.5 \mu \mathrm{m}$ long. Only occasionally they branched. The projections reach to the surrounding ground matrix. Exceptionally pinocytotic vesicles were detected.

Lipid droplets were regularly found in the cytoplasm of chondrocytes. They were coated with smooth membranes and located near the glycogen deposits.

Glycogen was only found in cells located in the deeper portion of the layer, it was practically absent from cells in the superficial zone of this layer (Fig. 7 and 8). It was present in form of alpha granules and it occupied rather large areas of the cytoplasm, surrounding the lipid droplets or their remnants.

Cytoplasmic fibrillar structures were not present in chondrocytes of the superficial layer of the fetal cartilage.

\section{Middle layer}

Chondrocytes of the middle layer of the joint cartilage differed from those of the superficial layer in shape, location and content of cytoplasmic fibrillar structures and inclusions. The chondrocytes were spindle-shaped or oval and $8-10 \times 12-15 \mu \mathrm{m}$ in size. They were located single or in pairs in more or less visible envelopes (Fig. 9 and 10). Also in the middle layer, the submicroscopic composition of the cells differed slightly between the surface and deep area of this layer.

The nucleus, nuclear envelope, chromatin and nucleolus showed no differences as against those in cells of the superficial layer (Fig. 9 and 10).

The cytoplasm. In cells of the superficial and deep zone of the middle layer different numbers and arrangement of cell organelles and fibrillar structures were found.

Granular endoplasmic reticulum of the superficial zone of the middle layer (Fig. 9) appeared as flattened cisterns surrounding the nucleus. In the apical portion of the cell the cisterns were parallel to each other. From club-shaped, widened cisterns vesicles were separated and moved to cytoplasm. Both the cisterns and vesicles were densely packed with ribosomes. In chondrocytes of the deep zone of this layer the granular endoplasmic reticulum was composed of short, flattened cisterns and minute vesicles, irregularly disseminated in the cytoplasm between the filaments (Fig. 10).

Agranular endoplasmic reticulum was only found in the cytoplasm of chondrocytes in the deep zone in form of few vesicles $0.3-0.4 \mu \mathrm{m}$ (exceptionally $0.8-1.0 \mu \mathrm{m})$ in size. They contained light, finely granular material.

The Golgi complex was not a regular finding in sectioned cells of this layer. When found, it was usually smaller than in cells of the superficial layer.

Mitochondria were found more often than in the superficial layer; rod-like, elongated shapes dominated (Fig. 9 and 10). In cells of the superficial zone they were located between the cisterns of the granular endoplasmic reticulum, in 


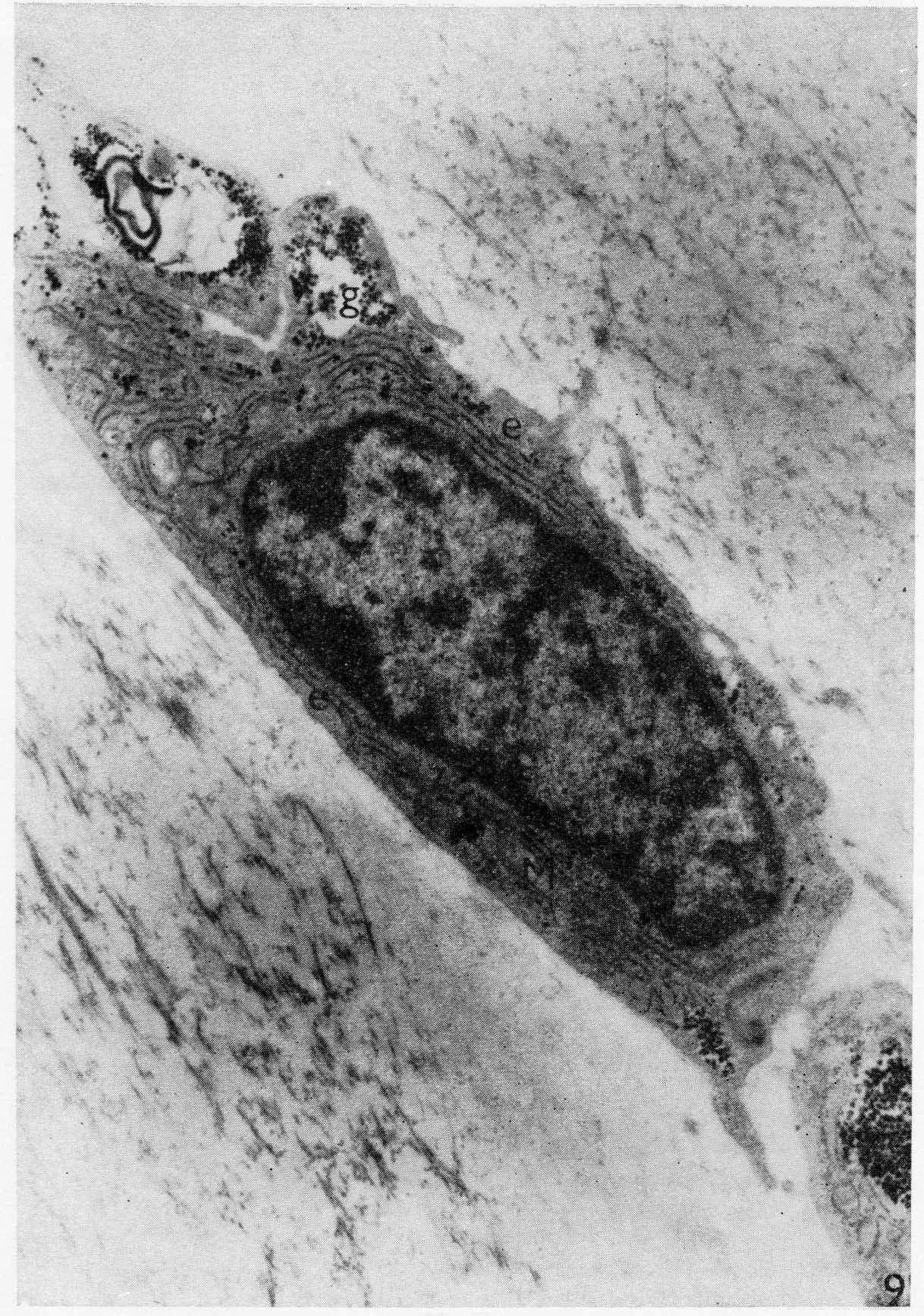

Fig. 9

Chondrocyte in the superficial zone of the middle layer of the bovine fetal joint cartilage. The nucleus $(\mathrm{N})$, zonula nucleum limitans $(\mathrm{z})$. In the cytoplasm flat cisterns of the granular endoplasmic reticulum (e), mitochondria $(M)$ of oblong shapes $(M)$, glycogen $(\mathrm{g})$ is concentrated in fields in the peripheral cytoplasm. The arrangement of cell membrane does not differ from that found in cells of the superficial layer. $\times 21400$. 


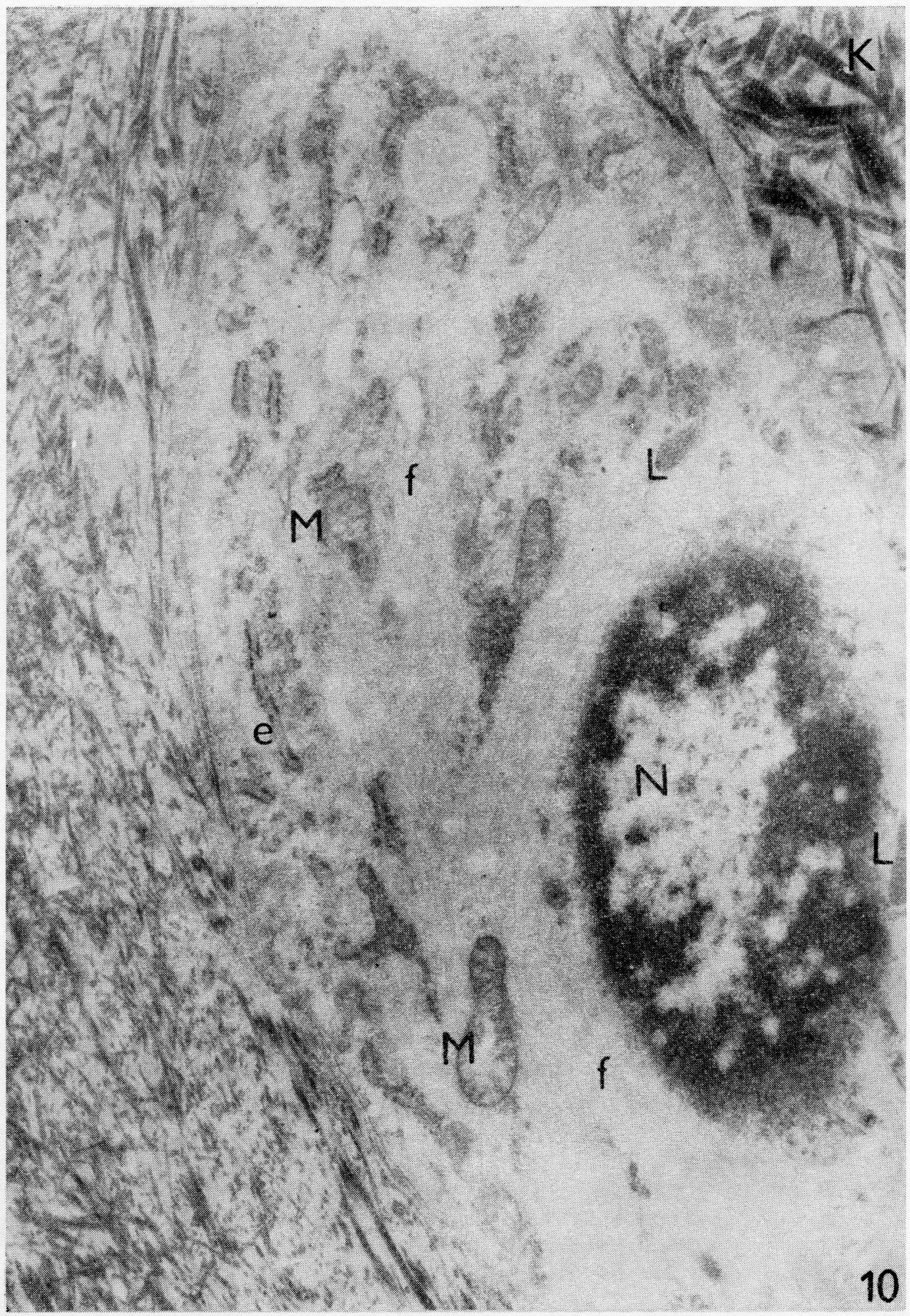

Fig. 10

A chondrocyte in the deeper zone of the middle layer of the fetal bovine joint cartilage. A part of the nucleus $(\mathrm{N})$ surrounded with large bundles of filaments (f), occupying large portions of the cytoplasm. Among them, irregularly disseminated mitochondria (M) of oblong shapes and short cisterns of granular endoplasmic reticulum (e) and lysosomes (L). The cell membrane with no larger irregularities adjoining the intercellular substance with coarse collagenous fibrils $(\mathrm{K})$ showing distinct periodicity, $\times 21400$. 
chondrocytes of the deeper zone they were found in areas filled with filaments.

Lysosomes were regularly detected in the cytoplasm of cells in the deeper zone while almost none were present in chondrocytes of the superficial zone of the middle layer.

Cell membrane. In cells of the superficial zone it was arranged in the same way as in chondrocytes of the superficial layer, only between the pairs of chondrocytes in the lacuna, contact without intercellular supporting structures was visible. In cells of the deeper zone, appearing mostly single in lacunae, the cytoplasmic surface was smooth so that the cell membrane was in contact with the intercellular matrix along the entire circumference of the membrane.

Lipid droplets occurred in similar numbers and appearance as in the superficial layer, whereas in the cytoplasm of chondrocytes in the deeper zone of the middle layer they were not detected. The same was true of glycogen.

Cytoplasmic fibrillar structures occurred only in the cytoplasm of cells in the deeper zone of the middle layer of cartilage. The filaments joined to large bundles surrounding the nucleus (Fig. 10) and filling almost entirely the cytoplasm except for a narrow rim near the cell surface. Between the bundles of filaments few cisterns and vesicles of the granular endoplasmic reticulum, mitochondria, and smooth vesicles $0.3-0.4 \mu \mathrm{m}$ in size were found.

\section{Deep layer of the cartilage}

Chondrocytes of the deep layer of the developing cartilage differed only slightly in size from those of the adult tissue. Differences were found in the numbers and arrangement of cell organelles, inclusions and their location in the ground substance. In the fetal cartilage, chondrocytes were mostly single in the lacunae, and no distinct columns perpendicular to the cartilage surface were observed.

The nucleus, nuclear envelope, chromatin and nucleolus did not differ from these structures found in the middle layer of an adult cartilage.

The cytoplasm. Characteristic feature of the cytoplasm of chondrocytes in the deep layer was a well developed granular endoplasmic reticulum, arranged in numerous short and usually dilated cisterns to which large numbers of ribosomes were attached. The cisterns contained moderately osmiophilic fibrillar material (Fig. 10).

Agranular endoplasmic reticulum occurred only rarely and formed smooth, electron-empty vesicles.

The Golgi complex was not conspicuous and it occupied small areas of the cytoplasm.

Mitochondria were scarce and did not differ from those of adult cells in this layer.

Lysosomes occurred regularly but in small numbers. Their sizes were 0.2 to $0.3 \mu \mathrm{m}$. Cell membrane formed numerous short projections along the entire cell surface so that the chondrocytes assumed a spiked appearance. The projections reached the pericellular matrix. Few pinocytotic vesicles were found.

Cytoplasmic inclusions - neither lipid droplets and glycogen nor fibrillar structures were found in the cytoplasm of chondrocytes in the deep layer of fetal joint cartilage. In pericellular matrix between the cytoplasmic projections regularly round, electron dense granules of various sizes were detected. They did not enter the cytoplasm of chondrocytes. It was possibly material containing calcium ions. 


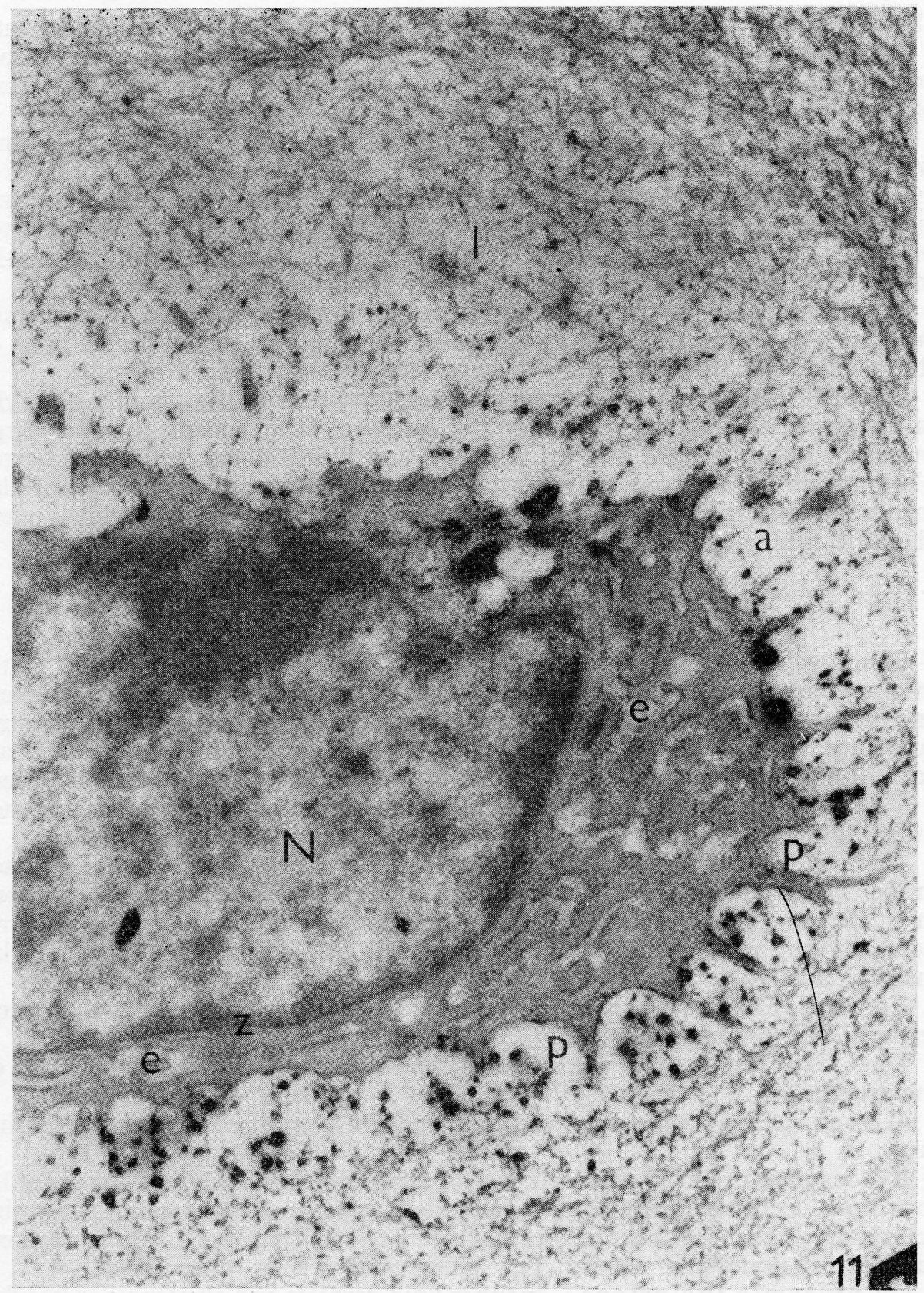

Fig. 11

A part of a chondrocyte from the deep layer of the fetal bovine joint cartilage. The nucleus (N) and thin zonula nucleum limitans $(\mathrm{z})$. The cytoplasm in dense and filled with cisterns of granular endoplasmic reticulum (e) that are usually dilated and contain material of fibrillar appearance. The cell membrane with numerous projections (p) reaching the pericellular zone (a) and intercellular matrix (I), containing numerous round, electron-dense granules, $\times 9800$. 


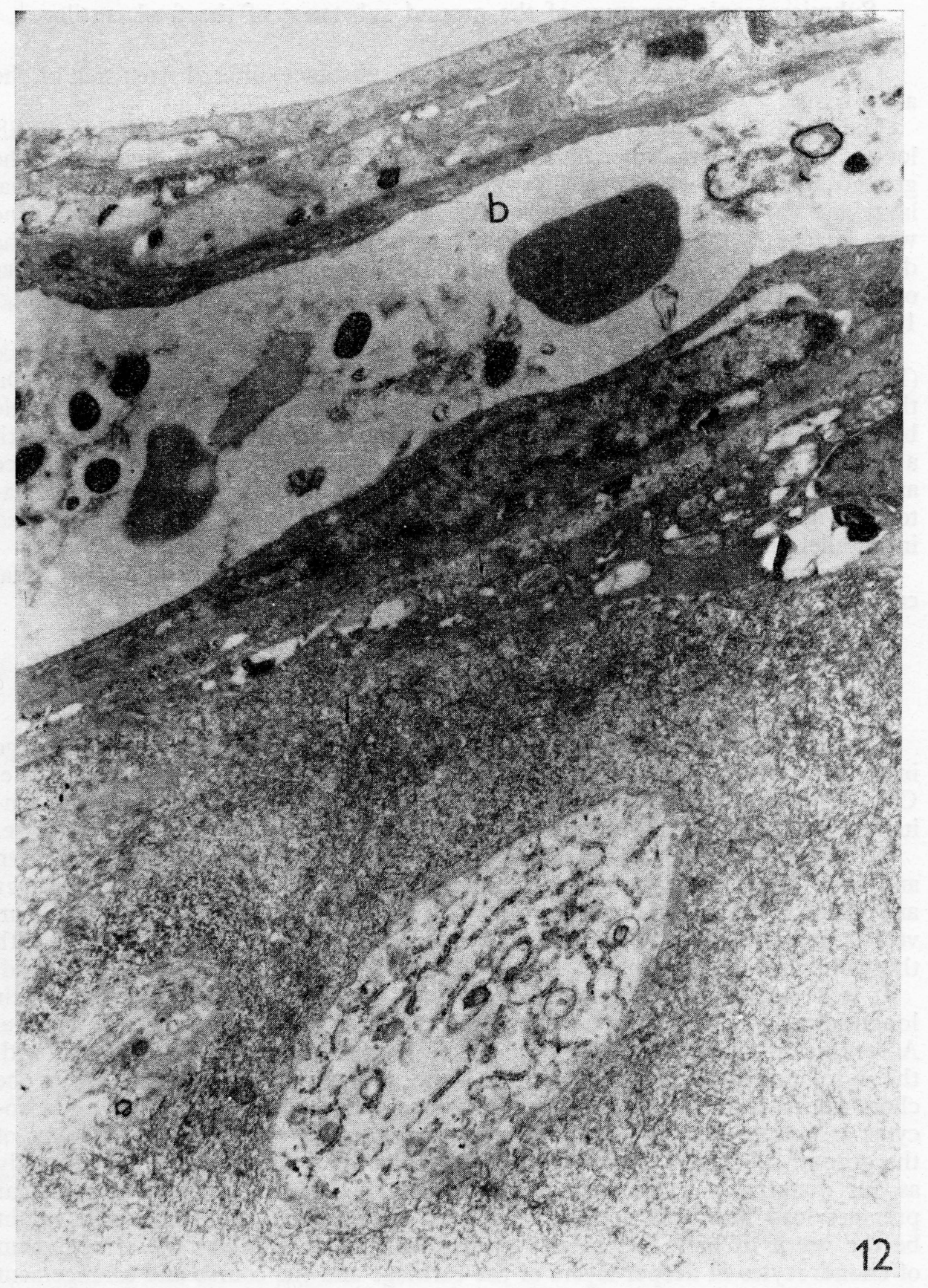

Fig. 12

A portion of the joint cartilage of a bovine fetus showing a blood vessel (b) penetrating into the pericellular substance (I). Beneath the vessel cytoplasm of chondrocytes of the superficial cartilage layer are visible. $\times 9800$. 
Submicroscopic structure of the ground substance of the fetal cartilage

The arrangement of fetal cartilage ground substance differed from that of the adult tissue.

The fibrillar component was composed of thin meshwork of collagen fibrils located in the ground amorphous substance quite irregular in arrangement. The ground amorphous substance prevailed. Around chondrocytes of the superficial layer and superficial zone of the middle layer no lacunae with pericellular zone were formed. Only in cells of the deep zone of the middle layer and those of the deep layer pericellular zone was formed with aperiodic fibrils and a circular orientation of collagen fibrils beyond the pericellular zone was suggested (Fig. 10 and 11$)$.

Of particular interest is the ground substance on the fetal cartilage surface (Fig. 7). There was no chondrosynovial membrane like in the adult cartilage. On the prevailing surface area of the fetal cartilage facing the joint cavity single bundles of collagenous fibrils were slightly prominent. They were covered with a thin layer of amorphous ground substance. Only short segments of the surface area of the joint cartilage were covered with a layer of darker, finely fibrillar material (Fig. 7) $0.1-0.2 \mu \mathrm{m}$ wide. These apparently were aperiodic fibrils, arranged in parallel and forming the chondral membrane.

Occasionally, blood vessels (Fig. 12) were seen in the superficial layer of fetal cartilage. These were never encountered in adult tissue.

\section{Discussion}

There are only few studies on the submicroscopic structure of the joint cartilage in cattle available. Wolf (1975) compared the joint cartilage of cattle and horse, Orys chak et al. (1974) investigated only selected structures (zonula nucleum limitans), Smith et al. (1967) described the arrangement of the ground substance.

Development of the joint cartilage has not been studied extensively; Cameron and Robinson (1958) compared the epiphyseal and articular matrix, Brower and $\mathrm{Hsu}$ (1971) investigated the blood supply and diffusion of substances from vessels into the ground substance. Therefore we shall confront our findings with those obtained in other mammals including man as far as they are generally valid.

It is a well-known fact that chondrocytes in the superficial layer have their longitudinal axes parallel to the cartilage surface due to effects of external pressure. According to Gould et al. (1974), however, this orientation is connected with the development of ground substance. The authors have suggested that in the chondrification centre spiral-shaped structures are forming and that the chondrocytes at periphery of the cartilage are compressed by the increasing amount of the ground substance. This view should be, no doubt, considered in this study as our material was collected at a stage of development when only muscular pressure load had been applied. The final arrangement of chondrocytes might be the result of both factors acting, especially if we consider the arrangement of chondrocytes in deeper layers of the cartilage and the course and arrangement of the fibrillar ground substance.

Zonula nucleum limitans has been described in our earlier papers (Horký et al. 1975; Horký 1980) and especially in that of Oryschak et al. (1974). It has also been found to exist in cattle. In our material, however, it was only found 
in fetal cartilage. In the opinion of Orys chak et al. (1974) its thickness increases with advancing age as indicated by his findings in rabbit cartilage. Its origin and function have not yet been elucidated.

In view of the function of chondrocytes as producers of the ground substance, granular endoplasmic reticulum, ribosomes, and the Golgi complex are the most important structures. Our data correspond with those of Davies et al. (1962), Palfrey and Davies (1966), Lamar et al. (1980) as far as the numbers, appearance and arrangement of these organelles are concerned.

The role of lysosomes which are not a particularly frequent structure in chondrocytes, have been studied by many authors. However, the best description of their function is that of Oryschak and Ghadially (1976). Our data on their appearance size and frequency in chondrocytes of the individual layers confirm the findings presented in literature.

Lipid droplets and glycogen were found in numbers and locations similar to those described by other authors (Stockwell 1967). We cannot, however, confirm the findings of Ghadially et al. (1965) who found lipid droplets located extracellularly in all cartilage layers.

Cytoplasmic fibrillar structures are regularly present in chondrocytes of the superficial and middle layers of both adult and fetal cartilage. Data concerning these structures are very scarce.

Greatest differences in arrangement of the ground substance of both adult and fetal cartilage were detected in its superficial layer, called chondrosynovial membrane (Wolf 1975). This layer plays a key role in the joint mechanics. It is composed of fine fibrils $4-10 \mathrm{~nm}$ wide which are located in the ground amorphous substance. In our material, its width varied between $0.5-1 \mu \mathrm{m}$ (adult cartilage) in good agreement with data of other writers. We found the fetal cartilage surface to differ in composition from the adult tissue. A greater part of the joint cartilage lacks this chondrosynovial membrane. In the fetal period covered by our study in small areas of the cartilage surface the fibrils in the uppermost layer were condensed and began to form the chondrosynovial membrane. No similar findings have been reported in literature as yet. Similar differences were found in the arrangement of collagenous fibrils in the developing cartilage, where in the superficial layers and in the transition area between the superficial and middle layers no lacunae with pericellular matrix had been formed as yet. They were only found in the depth of the middle layer and in the deep layer. It can be assumed that both formation of the chondrosynovial membrane and formation of typical lacunae is due to pressure on the cartilage surface. The presence of blood vessels and its species specificity has been described earlier (Brower and Hsu 1969; Wolf 1975).

\section{Ultrastruktura kloubní chrupavky skotu v ontogenesi}

Ke studiu ultrastruktury kloubní chrupavky skotu byly odebrány vzorky této tkáně od 3 dospělých jedinců ve stáŕí $3-5$ let a od 4 jedinců ve stáŕí $246-271$ dnů po oplození. Materiál byl odebrán jednak z karpálního, jednak z kyčelního kloubu, a to jak pro světelnou, tak elektronově mikroskopickou histologii.

Byla sledována ultrastruktura chondrocytů kloubní chrupavky, mezibuněčné hmoty a její uspořádání a utváření povrchu této specializované chrupavkové tkáně u dospělých jedinců a během vývoje. 
V obou typech chrupavky lze odlišit tři vrstvy: povrchovou, střední a hlubokou, mezi nimiž u vyvíjející se chrupavky lze najit zóny přechodné. Tyto vrstvy se liší jak ultrastrukturou chondrocytů, tak i uspořádáním mezibuněčné hmoty.

Chondrocyty jsou uloženy $\mathrm{v}$ povrchové vrstvě paralelně $\mathrm{s}$ povrchem chrupavky jednotlivě. Zonula nucleum limitans je zřetelně vytvořena $u$ chondrocytů vyvíjející se chrupavky. $Z$ cytoplasmatických inkluzí je glykogenu více v buňkách vyvíjející se chrupavky. Charakteristickým znakem cytoplasmy dospělých chondrocytů jsou svazečky aperiodických filament, zatímco u chondrocytů ve vývoji v této vrstvě chybějí.

Ve střední vrstvě chrupavky dospělé jsou chondrocyty uloženy v dobře vytvořených pouzdrech základní hmoty, která u vyvíjející se chrupavky jsou jen naznačena. $Z$ cytoplasmatických inkluzí u chondrocytů ve vývoji je nápadný glykogen, kterého je u dospělých malé množství. Vláknité struktury jsou v chrupavce fetu početné.

Chondrocyty hluboké vrstvy dospělé chrupavky jsou umístěny po $2-3$ ve společném pouzdru. Množství a uspořádání buněčných organel odpovídá vrstvě střední. $Z$ cytoplasmatických organel je nápadné množství glykogenu. U vyvíjející se chrupavky jsou chondrocyty v hluboké vrstvě umístěny jednotlivě v pouzdrech. $\mathrm{V}$ cytoplasmě prominuje granulární endoplasmatické retikulum, inkluze a vláknité struktury se prakticky nevyskytují.

Povrch dospělé kloubni chrupavky je kryt chondrální membránou, která u vyvijející se chrupavky na většině povrchu chybí a objevuje se pouze $\mathrm{v}$ malých okrscích.

\section{Ультраструктура суставного хряща крупного рогатого скота в онтогенезе}

С целью изучения ультраструктуры суставного хряща кругного рогатого скота были отобраны образцы у 3 взрослых животных в возрасте $3-5$ лет и 4 животных в возрасте 246-271 сутки после осеменения. Материал отбирали из карпального и тазобедренного суставов для световой и әлектронномикроскопической гистологии.

Проводились исследования ультраструктуры хондроцитов суставного хряцца, межклеточной массы и ее расположения, а также образования поверхности упомянутой специализированной хрящевой ткани у взрослых животных и в ходе развития.

$\mathrm{У}$ обоих типов хряща можно различить три слоя: поревностный, средний и глубокий, между которыми у развивающегося хряща можно обнаружить промежуточные зоны. Данные слои отличаются не только ультраструктурой хондроцитов, но и распорядком межклеточного вещества.

Хондроциты расположены в поверхностном слое параллельно с поверхностью хряща по отдельности. Zonula nucleum limitans четко образована у хондроцитов развивающегося хряща. Из цитоплазматических телец гликоген больше встречается в клетках развивающегося хряща. Характерным признаком цитоплазмы взрослых хондроцитов являются пучки апериодических филаментов, между тем как у хондроцитов в развитии они в данном слое отсутствуют.

В среднем слое взрослого хряща хондроциты расположены в хорошо образовавщихся капсулах основной массы, которые у развивающегося хряша лишь намечаются. Из цитоплазматических телец у развивающихся хондро- 
цитов примечателен гликоген, который у взрослых встречается в небольшом количестве. Волокнистые структуры в хряще зародыша многочисленны.

Хондроциты глубокого слоя взрослого хряща расположены по $2-3$ в совместной капсуле. Численности и расположение клеточных органелл соответствует среднему слою. Из цитоплазматических органелл четко выделяется количество гликогена. Хондроциты развивающегося хряща расположены в глубоком слое отдельно в капсулах. В цитоплазме выступает зернистая эндоплазматическая сетка, инклюзии и волокнистые структуры фактически не встречаются.

Поверхность взрослого суставного хряща покрыта хондральной мембраной, которая у развивающегося хряща в большинстве случаев отсутствует и появляется лишь на небольших участках.

\section{References}

ANDERSON, H. C. - SAJDERA, S. W.: The fine structure of bovine nasal cartilage. Extraction as a technique to study proteoglycans and collagen in cartilage matrix. J. Cell Biol., 49, 1971: $650-663$.

BARNETT, C. H. - COCHRANE, W. - PALFREY, A. J.: Age changes in articular cartilage of rabbits. Ann. rheum. Dis., 22, 1963: 389-400.

BARNETT, C. H. - DAVIES, D. V. - MacCONAILL, M. A. : Synovial joints: Their structure and mechanics, Longmans Green, London, 1961.

BONI, M. - MONTELEONE, M.: L'ultrastructura della cartilagine articolare in condizioni normali e in aleune condizioni patologiche. Ortopedia e Traumatologia, 25, 1957: 279-335.

BOZDĚCH, Z. - HORN, V. - HORKÝ, D.: Patogeneze artrózy. Čas. lék. čes., 113, 1974: $969-971$.

BROWER, T. D. - HSU, WAN-YI : Normal articular cartilage. Clin. Orthop., 64, 1969: 9-17.

CAMERON, D. A. - ROBINSON, R. A.: Electron microscopy of epiphyseal and articular cartilage matrix in the femur of the newborn infant. J. Bone Jt Surg., 40 A, 1958: 163-170.

DAVIES, D. V. - BARNETT, C. H. - COCHRANE, W. - PALFREY, A. J.: Electron microscopy of articular cartilage in the young adult rabbit. Ann. rheum. Dis., 21, 1962: 11-22.

DOIGE, C. - HOROWICZ, A.: A study of articular surfaces and synovial fossae of the pectoral limb of swine. Can. J. Comp. Med., 39, 1975: 7-16.

FEWER, D. - THREADGOLD, J. - SHELDON, H.: Studies on cartilage. 5. electron microscopic observations on the autoradiographic localisation of $\mathrm{S}^{35}$ in cells and matrix. J. Ultrastruct. Res., 11, 1964: 166-172.

GARDNER, D. L. - O'CONNOR, P. - OATES, K.: Low temperature scanning electron microscopy of dog and guinea-pig hyaline articular cartilage. J. Anat., 132, 1981: 267-282.

GARDNER, D. L. - WOORWARD, D.: Scanning electron microscopy and replica studies of articular surfaces of guinea-pig synovial joints. Ann. rheum. Dis., 28, 1969: 379-391.

GHADIALLY, F. N. - MEACHIM, G. - COLLINS, D. H.: Extra-cellular lipid in the matrix of human articular cartilage. Ann. rheum. Dis., 24, 1965: 136-146.

GOULD, R. P. - SELWOOD, L. - DAY, A.: The mechanism of cellular orientation during early cartilage formation in the chick limb and regenerating amphibian limb. Exp. Cell Res., 83, 1974: 287-296.

HORKÝ, D.: Submicroscopic structure of human joint cartilage. Acta vet. Brno, 49, 1980: $145-176$.

HORKÝ, D. - BOZDĚCH, Z. - HORN, V.: Ultrastructure of the synovial membrane and the joint cartilage in haemophilia observed in a transmission and scanning electron microscope. In: Modern trends in orthopedic surgery. Acta Fac. Med. Univ. Brun., 52, 1975: 195-210.

KAWIAK, J. - MOSKALEWSKI, S. - DARZYNKIEWICZ, Z.: Isolation of chondrocytes from calf cartilage. Exp. Cell Res., 39, 1965: 59-68.

LAMAR, CH. - VAN SICKLE, D. C. - BRANDMAN, P. - HINSMAN, E. J.: Ultrastructure of timed isolates of in vitro canine articular chondrocytes. Am. Vet. J. Res., 41, 1980: $241-243$.

LUST, G. - PRONSKY, W. - SHERMAN, D.: Biochemical and ultrastructural observations in normal and degenerative canine articular cartilage. Ann. J. Vet. Res., 33, 1972: 2 429-2 440.

McCALL, J. G.: Load deformation response of the micro-structure of articular cartilage. In: Lubrication and wear in joints. (V. Wright, ed.). London: Sector Publ. Lim. 1969a. 
MEACHIM, G.: Age changes in articular cartilage. Clin. Orthop., 64, 1969: 33-44.

MEACHIM, G. - STOCKWELL, R. A.: Adult articular cartilage. (Freeman, M. A. R., ed.), Alden Press, Great Britain, Oxford, 1973.

MUIR, I. H. M.: Biochemistry. In :Adult articular cartilage. 100-130, (Freeman, M. A. R., ed.), Alden Press, Great Britain, Oxford, 1973.

OAKES, B. W. - HANDLEY, C. J.: The ultrastructural morphology and biochemistry of chick chondrocytes in culture. Amer. J. Anat., 118, 1974: 390-391.

ORYSCHAK, A. F. - GHADIALLY, F. N.: Aurosome formation on articular tissues after parentenal administration of gold. J. Pathol., 119, 1976: 183-185.

ORYSCHAK, A. F. - GHADIALLY, F. N. - BHATNAGAR, R: Nuclear fibrous lamina in the chondrocytes of articular cartilage. Amer. J. Anat., 118, 1974: $511-515$.

PALFREY, A. J. - DAVIES, D. V.: The fine structure of chondrocytes. Amer. J. Anat., 100, 1966: 213.

ROSENBERG, L. - HELLMAN, W. -- KLEINSCHMIDT, A. K.: Macromolecular models of protein-polysaccharides from bovine nasal cartilage based on electron microscopic studies. J. biol. Chem., 245, 1970: $4123-4130$.

SILBERGER, R. - SILBERGER, M. - VOGEL, A. - WETTSTEIN, W.: Ultrastructure of articular cartilage of mice of various ages. Amer. J. Anat., 109, 1961: 251-275.

SMITH, J. W. - PETERS, T. J. - SERAFINI-FRACASSINI, A.: Observations on the distribution of the protein-polysaccharide complex and collagen in bovine articular cartilage. J. Cell Sci., 2, 1967: 129-136.

STOCKWELL, R. A.: The ultrastructure of cartilage canals and the surrounding cartilage in the sheep fetus. Amer. J. Anat., 109, 1971.

STOCKWELL, R. A.: Cell density, cell size and cartilage thickness in adult mammalian articular cartilage. Amer. J. Anat., 108, 1971 b: 584.

STOCKWELL, R. A.: The interrelationship of cell density and cartilage. Amer. J. Anat., 109, 1971a: $411-421$.

STOCKWELL, R. A.: The lipid and glycogen content of rabbit articular hyaline and non-articular hyaline cartilage. Amer. J. Anat., 102, 1967: 87-94.

VIGNON, E. - ARLOT, M. - PATRICOT, L. M. - VIGNON, G.: The cell density of human femoral head cartilage. Clin. Orthop., 121, 1976: 303-308.

WILTBERGER, H. - LUST, G.: Ultrastructure of canine articular cartilage: comparison of normal and degenerative (osteoarthritic) hip joints. Amer. J. Vet. Res., 36, 1975: 727-740.

WOLF, J.: Blood supply and nutrition of articular cartilage. Folia morph., (Prague) 23, 1975: $197-209$. 